\title{
DEMOCRACY AND PLURAL VOTING IN JOHN STUART MILL'S POLITICAL THOUGHT
}

\author{
DEMOCRACIA E VOTO PLURAL NO PENSAMENTO POLÍTICO DE JOHN \\ STUART MILL
}

\author{
ÁTILA AMARAL BRILHANTE \\ (UFC / Brasil) \\ FRANCISCO JOSÉ SALES ROCHA \\ (UFC / Brasil)
}

\begin{abstract}
RESUMO
Este artigo é destinado a mostrar que a defesa do voto plural empreendida por John Stuart Mill não é compatível com as linhas gerais da sua concepção de democracia. Objetivando combater a tirania das massas, Mill propôs que os votos tivessem valores diferenciados de acordo com o padrão educacional dos cidadãos. Ele não percebeu, entretanto, que tal proposta desestimula a participação da maioria do eleitorado na vida pública e estabelece uma equivalência entre conhecimento político e expertise em assuntos de governo, o que, em certa medida, enfraquece as suas credenciais democráticas. Mill objetivou criar um equilíbrio de poder que possibilitasse aos eleitores de nível educacional mais elevado ter alguma influência no processo político, o que, segundo ele, não aconteceria se aos votos tivessem o mesmo valor. O sistema plural de votação que ele propôs, entretanto, tendia a dar a impressão de que ele estava desrespeitando o eleitor comum e criando arbitrariamente uma aristocracia eleitoral.
\end{abstract}

Palavras-chave: voto plural; participação; competência; controlabilidade; democracia

\begin{abstract}
This article is intended to show that John Stuart Mill's defence of plural voting is at odds with the general lines of his conception of democracy. Intending to oppose the tyranny of the masses, Mill proposed that votes should be valued according to the standards of education of citizens. He failed to perceive that such a proposal does not stimulate the participation of most of the electorate in public life and equates political knowledge to expertise in governmental issues what to a certain extent weakens his democratic credentials. Mill aimed at creating a balance of power that allowed the voters with higher levels of education to have some influence in the political process what he thought would not occur if votes had the same value. The plural voting system he proposed, however, tended to impart the impression that he was disrespecting the common voter and arbitrarily creating an electoral aristocracy.
\end{abstract}

Key-words: plural voting; participation; competence; accountability; democracy 


\section{Introduction}

This article is devoted to the task of showing that John Stuart Mill's (hereafter referred to as Mill) defence of plural voting is at odds with the general lines of Mill's democratic ideals. He failed to perceive that his proposal of valuing the votes of citizens according to their standards of education was not appropriate to stimulate the participation of most of the electorate in public life and tended to incorrectly equates political knowledge to expertise in governmental issues. The second section presents the plural voting system proposed by Mill and points out the fact that it is deeply associated with his general concern with accountability. The third section relates the system presented with Mill's understanding of the importance of participation and intellectual excellence to public life. The fourth section outlines his baseline conception of equality according to which everyone, except the illiterate, was entitled to a basic level of control over the government, but leaving further influence to those who possessed more of that knowledge of the affairs of the community. It is claimed that Mill did not handled properly this issue because he failed to see that the plural voting system he proposed was unable to favour people's participation at the political process due to the fact that it tended to create a type of aristocracy of voters, leaving the other voters with the perception that they worth less than the others. The concluding section argues that he fail to prove that his plural voting system favours democracy and accountability. It is important to keep in that this article

\section{Plural voting}

In a letter to Edward Herford on 22 January 1850, Mill stated that progress was coming to a halt due to the low intellectual and moral states of all classes (See CW, v.19, p. 45). Throughout the 1850 s he took on the task of designing an electoral system capable of providing a fair representation for the educated minority, because he thought this was necessary to raise the level of political leadership and prevent the majority from imposing uniformity. In discussion with Harriet Taylor, he drafted a programme of electoral reforms in 1853. The programme was subsequently improved and was published in 1859 under the title Thoughts on Parliamentary Reform. In this work Mill advocated the introduction of an electoral system that required a basic level of education for the franchise and the adoption of a plural voting system that weighted the 
number of votes according to the educational level of citizens. He deemed those institutional mechanisms necessary for the promotion of participation and competent leadership. Mill believed that participation in the electoral process was important to train the popular mind both intellectually and morally. This is why he claimed that 'all governments must be regarded as extremely imperfect, until everyone who is required to obey the laws, has a voice, or the prospect of a voice, in their enactment and administration' (CW, v. 19b, p. 322-323).

For Mill, citizens were entitled to choose those who were responsible for the political decisions that affected society and to have a voice in matters of administration. Nevertheless, he did not accept that everyone ought to have an equal voice in such matters. Mill agreed with the view that everyone 'has an equal claim to control over his own government' (CW, v. 19b, p. 322323). But he saw the power that the suffrage gave as a power over others, and in this case "the claims of different people to such power differ as much, as their qualifications for exercising it beneficially' (CW, v. 19b, p. 322-323). Mill rejected the view that everyone was entitled to an equal claim to power over others, and accepted the view that the educated few should exert more power over others because they possessed more knowledge applicable to the affairs of the community. Based on this presumed superiority of knowledge, Mill advocated granting a greater weight to the suffrage of better-educated voters. In Thoughts on Parliamentary Reform (CW, v. $19 b$, p. 324-325), he defended the notion that the value of the vote of every person should be proportionate to their level of education:

\footnotetext{
If every ordinary unskilled labourer had one vote, a skilled labourer, whose occupation requires an exercised mind and knowledge of some of the laws of external nature, ought to have two. A foreman, or superintendent of labour, whose occupation requires something more of general culture, and some moral as well as intellectual qualities, should perhaps have three. A farmer, manufacturer, or trader, who requires a still larger range of ideas and knowledge, and the power of guiding and attending to a great number of various operations at once, should have three or four. A member of any profession requiring a long, accurate, and systematic mental cultivation - a lawyer, a physician or surgeon, a clergyman of any denomination, a literary man, an artist, a public functionary (or, at all events, a member of every intellectual profession at the threshold of which there is a satisfactory examination test) ought to have six. A graduate of any university, or a person freely elected a member of any learned society, is entitled to at least as many.
}

Mill's conviction that educated voters should be allowed more influence in the choice of their representatives was mainly grounded on the belief that such persons had more knowledge applicable to the affairs of the community, but also grounded to some extent on a very low ethic@-Florianópolis v. 12, n. 1,p.53-65,Jun. 2013. 
estimation of the capacity of the uneducated man. He referred to the uneducated as 'superstitiously attached to the stupidest and worst of old forms and usages', as 'eager to clutch at whatever they have not and others have', and as 'incapable of clearly conceiving the rights of others' (CW, v. 19b, p. 327). Mill believed that deference to the intellectual excellence of the educated few was necessary in order to provide a balance between numbers and education, and thereby promote the well-being of society. Otherwise, the lowest on the educational scale would outvote the educated, and virtually exclude them from parliament. He proposed that adults, who had passed a test to assess their capacity in reading, writing, and performing basic arithmetic operations, should be enfranchised. In his view, demanding a very small amount of educational attainment as a condition of suffrage could prevent political disasters. He gave a dramatic example (CW, v. 19b, p. 327):

\footnotetext{
Reading, writing, and arithmetic are but a low standard of educational qualification; yet even this would probably have sufficed to save France from her present degradation. The millions of voters who, in opposition to nearly every educated person in the country, made Louis Napoleon President, were chiefly peasants who could neither read nor write, and whose knowledge of public men, even by name, was limited to oral tradition.
}

Mill (See CW, v. 19b, p. 326-327) thus advocated giving greater weight to the suffrage of the more educated voters as a precaution against unskilled representatives. However, it is important to understand that his proposed plural voting system was motivated primarily by a concern for accountability. He presumed that, if extra votes were not given to the educated minority, the majority would gather a considerable amount of power and be unanswerable to anyone. Controlling parliament without an effective opposition, the majority would tend to impose uniformity, which would be detrimental to the polity. For Mill, if a system of equality were introduced, for example, 'under universal suffrage, the class of mere manual labourers would everywhere form a large majority in any electoral district grounded solely on a local division of the country' (See CW, v. 19b, p. 329-330). A political system framed in this way disenfranchised the other members of society, and did not replicate properly the opinion prevailing in society. He tried to promote the involvement of the educated in politics because they were so greatly outnumbered by the uneducated, and, in a society in which power was passing to the hands of the masses, they are potential victims of tyranny.

Mill thought that the plural voting system that he proposed was democratic because, on ethic@-Florianópolis v. 12, n. 1,p.53-65,Jun. 2013. 
the one hand, it did not permit the majority to be outweighed by the minority; and, on the other hand, it allowed the minority to be represented in parliament (See CW, v. 19b, p. 328-329). He feared the exclusion of representatives of the educated few from parliament, and argued that the educated few were not likely to control society, since their lack of identification with the values prevailing amongst the majority of its members would hinder them from accumulating the power that would enable them to control people in general. Later, however, in Considerations on Representative Government, Mill recognized that, although unable to control the majority, the minority tended to have an influence in parliament greater than their numerical strength because they were better able to put forward arguments and perform the role of a centre of resistance against the ascendancy of the majority (See CW, v. 19a, p. 515-516). As a matter of fact, in Considerations on Representative Government, he maintained the same line of reasoning according to which the system of plural voting was necessary to preserve the educated from the class legislation of the uneducated, but must stop short of enabling the minority to introduce class legislation for their own benefit (See CW, v. 19a, p. 476). The utilitarian movement provided Mill with an historical example of a small group of people that had influenced society in a way that he regarded as positive. Their effectiveness may have also reinforced Mill's conviction that a minority could significantly improve society. For Mill, the utilitarian movement did well in advocating progressive changes in society, especially in the fields of electoral and welfare reform. The antagonism of ideas between representatives of the educated few and representatives of the majority who upheld the values prevailing in society was essential to democracy. As representatives of different interests, they tended to be more willing to scrutinise each other, because they held opinions that were generally at odds. For Mill, this scrutiny promoted accountability because, in checking each other, the minority and the majority were made answerable to society for their acts, and therefore were more likely to be controlled.

The main object of Mill's defence of plural voting system was to render government answerable to the people. If minorities were present in parliament, they could check the power of the majority. Accountability is also a feature of Mill's defence of open voting in Thoughts on Parliamentary Reform. His opposition to the secret ballot was based on the conviction that secrecy left electors unaccountable to their fellow citizens, which he deemed detrimental to society. The work Thoughts on Parliamentary Reform was Mill's first comprehensive attempt to give an institutional answer to his concern with the tyranny of the majority. His opposition to the 
radical tenet 'one man one vote' in this work shows that Mill was not willing to countenance equality in every right recognized by society. He rejected the idea that individuals were all equally enlightened, capable, and strong. Despite agreeing with the democratic reformers in having universal suffrage as an ultimate aim, he believed that inequalities must be recognized, because those of greater intelligence should manage public affairs (CW, v. 19b, p. 323-324):

A person who has not, either by reading or conversation, made himself acquainted with the wisest thoughts of the wisest men, and with the greater examples of a beneficent and virtuous life, is not so good as one who is familiar with these. A person who has even filled himself with this various knowledge, but has not digested it - who could give no clear and coherent account of it, and has never exercised his own mind, or derived an original thought from his own observation, experience, or reasoning, is not so good, for any human purpose, as one who has .... There is no one who, if he was obliged to confide his interest jointly to both, would not desire to give a more potential voice to the more educated and more cultivated of the two.

\section{Democracy, participation and intellectual excellence}

It is important to consider whether Mill's advocacy of a plural voting system compromises his democratic ideals. His fear of a democratic despotism seems to have led him to compromise such important democratic notions as equality and participation. The democratic ethos is marked by the idea of a presumed equality amongst citizens, who are not subjected to any sort of hereditary deference (See SIEDENTOP, 1979, p. 153). Mill certainly rejected hereditary deference. However, it is necessary to examine whether or not his deference to intellectual excellence, by granting additional votes to the educated, undermined his commitment to democracy.

The plural voting system proposed by Mill would have been detrimental to participation. It is quite difficult to imagine how those whose votes would have been worth less than others would have been motivated to engage in the political process in a context where the passion for equality was becoming increasingly influential. It seems reasonable to infer that, had Mill's proposal been implemented, it would have imparted to those who were not awarded additional votes the perception that they were not endowed with the same dignity as their fellow citizens whose opinions were seen to worth more (See JONES, 1983, p. 177-178). The system Mill 
proposed was framed in an aristocratic fashion establishing several levels of citizenry in which the vote of the educated was of greater value than the vote of the common citizen. The perception that their dignity is not being respected is likely to produce either resentment or apathy and thus to alienate people from the political process by leading them either to resentment or apathy. One might argue that it is an open question whether this would be the outcome were Mill's scheme to be implemented. This is not a sound objection, however, because, if each vote counted equally, people would be a lot more willing to be involved in the political process since their vote would be more influential.

As a utilitarian, Mill's commitment to plural voting depended on its contribution to the wellbeing of society. If it turned out that society would be better served by an equal voting system, then he would need to abandon plural voting. One can thus infer that Mill did not take seriously the possibility of resentment and apathy being the consequence of plural voting, because he assumed that the tyranny of the majority was the main threat to general happiness. It is, therefore, fair to say that Mill's defence of plural voting tended to reinforce the idea of an intellectual aristocracy in a period in which the longing for equality was growing stronger. In order to strengthen competence and create a well-qualified leadership, Mill diminished the value of participation as an instrument to promote civic culture and improve the masses. This seems to be in agreement with Mill's affirmation in his Autobiography that in the 1850s he was less democratic than he had been previously (See CW, v. 1, p. 239).

Mill never found acceptance among politicians for his idea of giving additional votes to those with a superior education. He said that those who desire any sort of inequality in the electoral vote, did so 'in favour of property and not of intelligence or knowledge' (See CW, v. 1, p. 261). The electoral system that Mill advocated in Thoughts on Parliamentary Reform was problematic both because the inequality in the vote which it advocated was more likely to alienate than to commit people to the political process, and because it demanded the identification of the various grades of political knowledge in order to establish the value of the votes. He campaigned in favour of the establishment of a system of National Education precisely to make such an identification and to rank the value of people's franchise. It appears, nevertheless, that Mill (BAUM, 2000, p. 264) underestimated the difficulties involved in the process of establishing a standard to define the level of valuable political knowledge that citizens have:

ethic@-Florianópolis v. 12, n. 1, p. 53 -65, Jun. 2013. 


\begin{abstract}
Still, political issues always involve both instrumental knowledge and moral judgments, and those persons who have technical proficiency in particular areas have no unique claim to moral competence. For instance, an economist can claim special expertise regarding, say, how raising the minimum wage will affect the level of unemployment in an economy, but they have no special moral competence concerning if, when, and how a society should adjust its minimum wage laws. Such policy decisions involve judgments about risks and ends that go beyond the technical expertise of economists.
\end{abstract}

It is important to note that the highly educated few are not free from prejudice and class bias (See TEN, 1998, p. 384). Mill does not seem to have paid attention to the fact that superiority in instrumental knowledge does not imply superiority in moral knowledge. It may be the case that those having university degrees do not intend to add to the general happiness but rather to pursue their selfish interests. Besides, instrumental knowledge refers to expertise or knowledge about specific aspects of social reality, while political knowledge is concerned, among other things, with sensitivity to people's expectations, strategic and tactical reasoning, the ability to negotiate and compromise, and a sense of opportunity. Defending plural voting, Mill assumed that he could measure the political knowledge that people possessed, and rank the value of their franchise accordingly. This is, however, groundless, because neither professional qualifications nor university degrees offer grounds for estimating the capability to choose representatives. The simple fact that someone has achieved a university degree or is a clergyman does not make him better able to choose a representative than a tradesman or a farmer, as Mill presumed. On the other hand, to reserve a special role for the educated in those functions of the executive branch of government that require considerable expertise in legal or administrative matters is justifiable. The technical support of experts can be valuable in various spheres of government, and it is especially valuable for those working in the bureaucracy (See THOMPSON, 1976, p. 55). Nonetheless, there is no expertise in society that offers a good enough reason why one should be seen as better able to vote than another. Clergymen have knowledge of things that tradesmen ignore, and vice versa, but to say that what one of the groups knows will enable them to make better electoral choices is itself a political matter. Besides, one cannot presume that every clergyman and tradesman has the same political leanings as the other members of the group to which they belong. It is, therefore, up to the political process to settle questions regarding policies, although technical expertise has an important role in implementing them.

In Thoughts on Parliamentary Reform, Mill assumed that majorities are homogeneous ethic@-Florianópolis v. 12, n. 1, p.53-65,Jun. 2013. 
within themselves and hostages to the tastes and feelings prevailing in society. It appears that he believed that the overwhelmingly powerful effects of the standardization that marked the nineteenth-century had spared only the members of the educated minority. This is why he also believed that the members of the educated minority were 'a certain group of people in the society somehow not influenced by politics though engaged in politics' (FULLER, 1971, p. 122). These beliefs contradict Mill's conviction expressed elsewhere that ordinary people would be ultimately able to identify and to defer to those better able to govern society if channels of communication and discussion were kept open. In this sense, there is a difference between the capacity to make decisions and the capacity to judge them (See MORROW, 1998, p. 171-2). In On Liberty, for example, Mill accepted that, although unable to formulate them due to lack of expertise, citizens were able to judge public decisions because they were the ones affected by them. So, Mill believed that the average man's capacities could not be rated highly, but that he nevertheless had the capacity to 'respond internally to wise and noble things, and be led to them with his eyes open' (CW, v. 18, p. 269).

\section{Political baseline equality}

Mill defended the exclusion of people unable to write, read, or count from the electoral process, alleging that they were incapable of making informed choices. He had already defended this idea many years earlier, based on the proposition that, as the press was the most important means of disseminating political views and general information, only those who were able to read were able to make informed choices (See CW, v. 18, p. 31). For Mill, it was wrong to allow those who lacked the information that would allow them to vote conscientiously to exercise power over others. This is not an invalid argument, providing the exclusion is temporary whilst people are educated to read and count (See STAFFORD, 1998, p. 116). This argument appears to be associated with a sort of baseline conception of accountability and participation. However, the notion of baseline equality exists in Mill's thought only in embryonic form. Berger elaborated upon such a notion. According to Berger, Mill's conception of equality precluded inequalities that degraded individuals by putting them under the complete control of others, because this was to deny their status as autonomous human beings (See BERGER, 1984, p. 159-161). This conception of equality can be used to explain Mill's defence of plural voting (See BERGER, 
1984, p. 159-161). In this way, the baseline conception of equality implied that everyone, except the illiterate, was entitled to a basic level of control over the government and to have an influence on its affairs. This was enough to respect the elector's condition of an autonomous human being, able to make choices and influence public life. Further deference, however, should be given, according to Mill, to those who possessed more of that knowledge which might be applied to the affairs of the community. So, the differentiation in the number of votes was expected to satisfy the claims of those who, in Mill's opinion, were qualified to make electoral choices which would be more beneficial to the entire community. There is no objective means of determining the number of votes each person should possess. The political process is too complex for that. The application of a conception of baseline equality to the electoral process shows that Mill was trying to accommodate the goals of participation and competence in the same conceptual framework. Nevertheless, in his account of plural voting, he clearly emphasized competence to the detriment of participation.

Mill would not have favoured inequalities that implied undue power over others because this would undermine the autonomy that was a central value in his political philosophy. $\mathrm{He}$ advocated the plural voting system on the assumption that it would increase general happiness by preventing the tyranny of the majority. But he failed to perceive that equal voting would have better suited his intention of promoting a liberal civic culture, because it conveys the sense that each person partake of a common dignity. The opposition that his proposal faced was a clear indication that people did not regard it as beneficial. Therefore, it would not have increased participation and added to the general happiness if it had been introduced, because it would have negatively affected people's self-respect, thus triggering resentment. Mill intended to bring the benefits of trained minds to bear on government in order to avoid the threats that, in his opinion, an overwhelming presence of unskilled representatives could pose to government. But he mistakenly assumed that this would not be possible if votes were counted equally. In point of fact, the line of reasoning Mill pursued in his defence of plural voting brought him close to a counter-argument to democracy, that is 'that the general public is too unintelligent, ill-informed, and inattentive to public affairs for a form of government that gives even marginal control over its policies to the mass of the people' (PENNOCK, 1979, p.154-155). He always defended the need for competent administration. In the $1850 \mathrm{~s}$, he extolled the Northcote-Trevelyan Report because it recommended the selection of civil servants by means of open competition. On 8 
March 1854, in a letter to Harriet Taylor, Mill commented that the selection of civil servants based on intellectual superiority could bring extremely positive results for society (See CW, v. 14, p. 184). But his defence of competent administration brought no problem of consistency to his political thought.

\section{Conclusion}

In view of what has been presented, it is apposite to point out that Mill compromised his belief in the potentialities of the people and his conviction that a perfect representative system should grant the suffrage to every adult. This implied that once a minimum level of education had been achieved, there was no more reason to give different weight to different people's influence on the electoral process. People who have university degrees are normally better able to occupy positions in government due to their expertise. However, Mill confused the capability of the educated to perform well in the bureaucracy with qualitative superiority in relevant political knowledge. His attempt to rank the value of the franchise betrayed the democratic ideals which underpinned most of his writings on political philosophy. Plural voting would have tended to generate apathy and resentment, which would prevent people from exchanging their experiences in a way that Mill deemed essential to produce improvements. Besides, there is no evidence that plural voting would have produced the sort of leadership that he aimed at. If people were alienated from the electoral process, there was no reason to think that they would engage in the task of keeping government accountable, which was his deeper concern. There is no doubt that Mill intended to create a balance of power that favoured the participation of people in the political process without marginalizing voters with higher levels of education. He was intending to render compatible the claims of competence with the claims of participation, but the plural voting system he proposed seemed more likely to generate apathy and resentment. 


\section{Bibliography}

BAUM, B. Re-reading Power and Freedom in John Stuart Mill. Toronto: Toronto University Press, 2000.

BERGER'S, F. R. Happiness, Justice and Freedom: The Moral and Political Philosophy of John Stuart Mill. Berkeley: University of California Press, 1984.

FULLER, T. John Stuart Mill and The Transformation of Politics in Representative Government, Utilitarianism and On Liberty. Tese (Ph.D/Political Science) - John Hopkins University, Baltimore, 1971.

JONES, P. Political Equality and Majority Rule. In: MILLER; SIEDENTOP (eds.). The Nature of Political Theory. Oxford: Clarendon Press, 1983.

MILL, John Stuart. Autobiography and Literary Essays. In: . The Collected Works of John Stuart Mill. Org. J. M. Robson et al. Toronto, London: University of Toronto Press, Routledge \& Keagan Paul. 1963-1991. v. 1.

. Considerations on Representative Government. In: The Collected Works of John Stuart Mill. Org. J. M. Robson et al. Toronto, London: University of Toronto Press, Routledge \& Keagan Paul. 1963-1991. v. 19a.

. Later Letters, 1849-1873. In: The Collected Works of John Stuart Mill. Org. J. M.

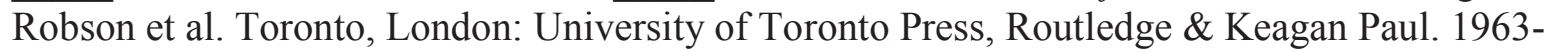
1991. v. 14.

. On Liberty. In: . The Collected Works of John Stuart Mill. Org. J. M. Robson et al. Toronto, London: University of Toronto Press, Routledge \& Keagan Paul. 1963-1991. v. 18.

. Rationale of Representation In: . The Collected Works of John Stuart Mill.

Org. J. M. Robson et al. Toronto, London: University of Toronto Press, Routledge \& Keagan Paul. 1963-1991. v. 18.

. Thoughts on Parliamentary Reform. In: The Collected Works of John Stuart Mill. Org. J. M. Robson et al. Toronto, London: University of Toronto Press, Routledge \& Keagan Paul. 1963-1991. v. 19b.

MILLER, Dale E. John Stuart Mill's Civic Liberalism. History of Political Thought, v. XXI, The Collected Works of John Stuart Mill n. 1, Spring 2000.

MORROW, J. A History of Political Thought. New York: New York University Press, 1998.

PENNOCK, J. R. Democratic Political Theory. Princeton: Princeton University Press, 1979.

SIEDENTOP, L. Two Liberal Traditions. In: RYAN, A (ed.). The Idea of Freedom: Essays in ethic@ - Florianópolis v. 12, n. 1, p. 53 - 65, Jun. 2013. 
Honour of Isaiah Berlin. Oxford: Oxford University Press, 1979.

STAFFORD, W. John Stuart Mill. London: Macmillan, 1998.

TEN, C. L. Democracy, Socialism, and the Working Classes. In: SKORUPSKI, J. (org.). The Cambridge Companion to Mill. Cambridge: Cambridge University Press, 1998.

THOMPSON, D. F. John Stuart Mill and Representative Government. Princeton: Princeton University Press, 1976. 